\title{
LEXICAL DISTORTION: A STUDY ON INDONESIAN-ENGLISH TRANSLATION
}

\author{
Ramli \\ Universitas Lakdende Unaaha \\ ramli.baharuddin@gmail.com
}

\begin{abstract}
Lexicon plays a fundamental role in translation. A good and acceptable translation should success rendering the message of source language into target language by selecting appropriate lexicon. The incorrectly lexical choice will distort the message of the source language. This paper investigates the lexical errors found in the translation of Indonesian text into English text made by the fifth-semester students. This qualitative study collects the data by administering a translation test to the respondents of 30 students. The data were analyzed using error analysis method following 5 steps: elicitation, registering, identifying, categorizing, and evaluating. The analysis and interpretation found that the lexical distortions can be categorized into: omission, overinclusion, misselection, disordering, and blending. Misselection is found to be the most dominant error followed respectively by omission, misordering, overinclusion, and blending. The findings show that the main problem of the translation is the wrong selection of lexicon and can contribute to the evaluation teachinglearning process either theoretically or practically. As a result, the improvement of students' translation quality requires students to practice more and more. In addition, the teaching of translation should be focused primarily on the selection of lexicon.
\end{abstract}

Keywords: lexicon, distortion error, translation, lexical selection, error analysis

\section{A. INTRODUCTION}

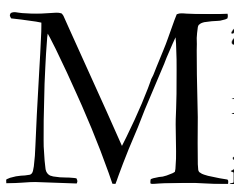

any linguists put definition on translation. This section provides some opinions from them. Firstly, translation is the general term referring to transferring of idea from one language into another language in any form of language (Brislin, 1976, p. 1). The second, Nida \& Taber (1982, p. 12) stated that translation involves with producing equivalent meaning from source language into the target/receptor language in two concerns; meaning and style. The next, Simatupang (2000, p. 2) focuses viewing the translation as rendering the source language meaning into the target language in the most natural form. The last, Newmark views translation as a competence to reproduce the message of one language in another one (2001, p.7). All notions provided by those scholars pointed that on translation involves some aspects as idea/message, source and target language, as well as equivalent in form and meaning.

The main problem experienced by the students in producing a good translation is the selection of the equivalence of (either in form or meaning) the source language (SL) in the target language (TL). The word choice will determine the success of rendering the message of source language into target language. The such dissimilarity between Indonesian and English language as grammar, culture, and concept is potential to generate problems in producing an 
acceptable translation (equivalent either in form or meaning). The misselecting of lexicon means the deviation of the message of source language being transferred as Llach (2011, p.75) suggested. Finally, it produces unsuccessful communication and eventually difficulties of communication may occur.

Error analysis in English as a second language is one of the methods that can be applied in mapping various types of errors in translation, one of which is the lexical level error. As Corder (1981, p. 45) suggests that error analysis can function as: 1) theoretically, means to check the process of language teaching-learning, and 2) practically, a feedback to decide a proper remedial treatment in solving the problems faced by the teachers and students. Applying error analysis can identify and follow up the errors by improving either the teaching materials or the teaching methods practiced in the classroom.

As an attempt to improve the teaching of translation by lecturers and the practice of translation for students, error analysis in translation - in terms of lexicon - needs to be carried out to explore the cases. The result can be used by lecturers as guidance to make improvement and for students it can show them their understanding and the ability in translating practice.

Based on the above discussion, the paper explored the lexical distortion as a part of lexical error in translation of Indonesian text into English in terms of: the types, the sources, and the impacts of lexical distortion errors made by the students in translating the Indonesian text into English.

\section{B. REVIEW LITERATURE}

\section{Language Error}

Brown (2007, p. 257) suggests that: "A mistake refers to a performance error that is either a random guess or a "slip", in that it is failure to utilize a known system correctly. ... An error, a noticeable deviation from the adult grammar of a native speaker, reflects the competence of the learner." His view on error involves the competence as a result of language deviation of grammar while mistake deals with the performance due to unable to apply the known rules of a language correctly.

The similar opinion was suggested by Setyawati (2010, p. 13) that error is something done incorrectly, deviated the norms or rules in terms of ignorance. Further, James (James, 1998) categorizes the deviation of language use into error and mistake. He suggested that the former is type of deviation which cannot be self-corrected as the students still need more relevant 
knowledge, while the latter is type of deviation that can be self-corrected when the students are shown the deviation they made.

To summarize, language error is a form of deviant language use in terms of the correct rules of a language. There two types of error: 1) error is a nonstandard use of language occurred systematically due to competence and 2) mistake is a nonstandard use language occurred unsystematically due to performance.

\section{Language Error Analysis}

Ellis \& Barkhuizen (2005, p. 51) suggested that error analysis consists of a set of procedures for identifying, describing, and explaining learner error. Following Corder procedures, Ellis comprehensively explains those steps in detail by providing more examples for each step (1994, pp. 49-67). The procedures consist of collecting language learner sample, identifying error, describing error, explaining error, and evaluating error.

In addition, Richard and Schmidt (2010a, p. 184) defined the error analysis as a study on errors made by the second language learners aimed at: 1) identifying the strategies learners utilized by the language learners, 2) recognizing the source of the errors, and 3) collecting information on the language teaching difficulties to provide guidance in planning teaching materials. In summary, error analysis studies the language errors following 5 steps: collecting, identifying, explanation, categorizing, and evaluating the errors.

\section{Language Error Sources}

There are three possible sources of language error: language interference previously acquired; ignorance of learner they use; and incomplete language teaching in class (Setyawati, 2010: pp. 15-16) . Other linguists concerning to language/second language teaching proposed intralingual and interlingual as the sources of errors (Richards \& Schmidt, 2002: 185). Intralingual comprises overgeneralizations, simplifications developmental errors, communication-based errors, induced errors, errors of avoidance, or errors of overproduction, while interlingual involves with first language/mother tongue interference (Murad, 2013). In addition, James also suggests four sources of errors as follow: interlingual, intralingual (1998, p. 83), and communicative strategy (1998, pp. 187-188).

The above discussion draws a conclusion that interlingual, intralingual, and communicative strategy are involved in the error production categorized as the sources of errors. Interlingual is concerning with the leaner first language, intralingual is regarding with the language being learned, and communicative strategy is involving the learners' competence in language learning. 


\section{Lexical Distortion}

Lexical distortion was chosen to study as there are many of errors could be made by the language learners as the focus of this paper to discuss. James (1998, p. 150) has classified lexical distortion into 5 types as follow:

1. Omission occurs when there is an element omitted i.e. in word intresting which should be interesting

2. Overinclusion is made by adding an element into the word (for example) which should not be i.e. addition of $n$ into word dinning room (the correct form: dining room) or the freshermen which should be freshmen.

3. Misselection is to miss selecting the correct form of lexeme as they share such common spelling near to identic as delitouse which should be delicious.

4. Misordering is ordering the element into wrong place. For example, the words littel, ferporate should be little and perforate irrespectively. In the phrasal level, we can find the boys little which should be the little boys.

5. Blending happens when two elements produce misunderstanding such as word deepths in phrase The deepths of the ocean formed by depth and deeps.

\section{Error Gravity}

Dulay, Burt, and Krashen (1982, p. 191) mentioned that there are two kinds of communication impacts that can occur due to language errors, namely: 1) significant communication impact caused by the error of the whole speech termed as global errors that cause communication difficulties of the speaker and 2) insignificant communication impact caused by error on a single element of speech or is called a local error that does not have an impact on misunderstanding. The speaker's intentions can still be understood by the other person.

\section{METHODOLOGY}

This qualitative research was carried out by content analysis technique. This method will: systematically, factually and accurately describe the lexical distortions found in the translation of Indonesian texts into English; identify the source of the distortions; and describe their impact on communication.

The researchers take a role as the main instrument in collecting the data. The students were tested to translate the Indonesian language text into English. The test administration was done at the time the students attending the course "Translation II". It followed the steps: first, the students were distributed Indonesian text, then, given direction to translate the text; the 
students were given 120 minutes (equivalent to 3 hours of learning); the results were collected for reviewing, identifying and classifying and evaluating the errors. Furthermore, the data were tabulated and analyzed descriptively according to the language error analysis procedures on lexical distortion.

The data analysis was performed according to the procedure of language error analysis proposed by several experts as already described previously in the theoretical review in the following steps:

1. Collected sample errors: record and collect error samples contained in translation results.

2. Identified errors. From the collected sample, further lexical errors are identified by category.

3. Explained the error. After identification, the lexical errors are described and described the source of the error.

4. Classified errors. Once described, the errors are classified according to the type of lexical error according to the focus of the study.

5. Evaluated errors. At this stage, the researcher will evaluate and correct the lexical errors that have been found and provide an alternative translation.

\section{FINDINGS AND DISCUSSION}

There were 1,274 distortions of lexis found in the translation investigated. The details were as follow: 1) omission 316 (17.59\%), 2) overinclusion 100 (5.57\%), 3) misselection 670 (37.31 $\%)$, 4) missordering 146 (8.13\%), and 5) blending 42 (7.34\%).

Table 1. Distribution of Lexical Distortion

\begin{tabular}{llcc}
\hline No. & \multicolumn{1}{c}{ Category } & Frequency & Percentage \\
\hline $\mathbf{1}$ & Omission & 316 & $15.65 \%$ \\
2. & Overinclusion & 100 & $4.95 \%$ \\
3. & Misselection & 670 & $33.18 \%$ \\
4. & Misordering & 146 & $7.23 \%$ \\
5. & Blending & 42 & $2.08 \%$ \\
& & 1.274 & $100 \%$ \\
\hline
\end{tabular}

The sources of errors were: 1) interlanguage, 2) intralanguage, and 3) communication strategy. And the effects of errors are: 1) local effect and 2) global effect. Table 1 and figure 1 portrait the lexical distortion found in the translation.

The missselection found to be the most dominant errors in lexical distortion. Misselection error occurs as the selection of lexical form in target language is not equivalent in meaning with source language lexeme. Thus, the meaning of the source language was distorted and not conveyed in the target language. An example of missselection error was:

Kebijakan sekolah gratis ini merupakan bentuk realisasi anggaran 20\% (SL) 
Foreign there free school is a form estimate realization $20 \%$ (TL)

This misselection is the word estimate for the meaning translated from word anggaran. Here, it is clearly understood that the words anggaran and estimate show a much different in meaning. Ultimately, the meaning of the source language transferred into the target language unsuccessfully conveyed. The equivalent of the word anggaran in English corresponding to the context of the source language text is budget. Some other examples:

(1)... foreign free school which purpose to advocated the program obligatory of study nine years. (TL)

... Kebijakan sekolah gratis yang bertujuan untuk mendukung program wajib belajar sembilan tabun (Wajar 9 tabun) (SL)

(2) Could the goverment as the central authority to complete these necessary? (TL)

Mampukah pemerintah sebagai otoritas pusat memenuhi kebutuban ini? (SL)

Those errors made by the respondents were caused by their ignorance of the equivalence of the SL lexemes in the TL forms. Therefore, those errors belong to interlanguage.

The second error which is dominant is omission. There are some features of errors made by the respondents. For example, almost all respondents made omission error $-n-$ for the word goverment for the equivalence of the word pemerintah. Here is the error data:

The goverment has tired to create and education system ... (TL)

Pemerintah telah berusaha menciptakan suatu sistem pendidikan... (TL)

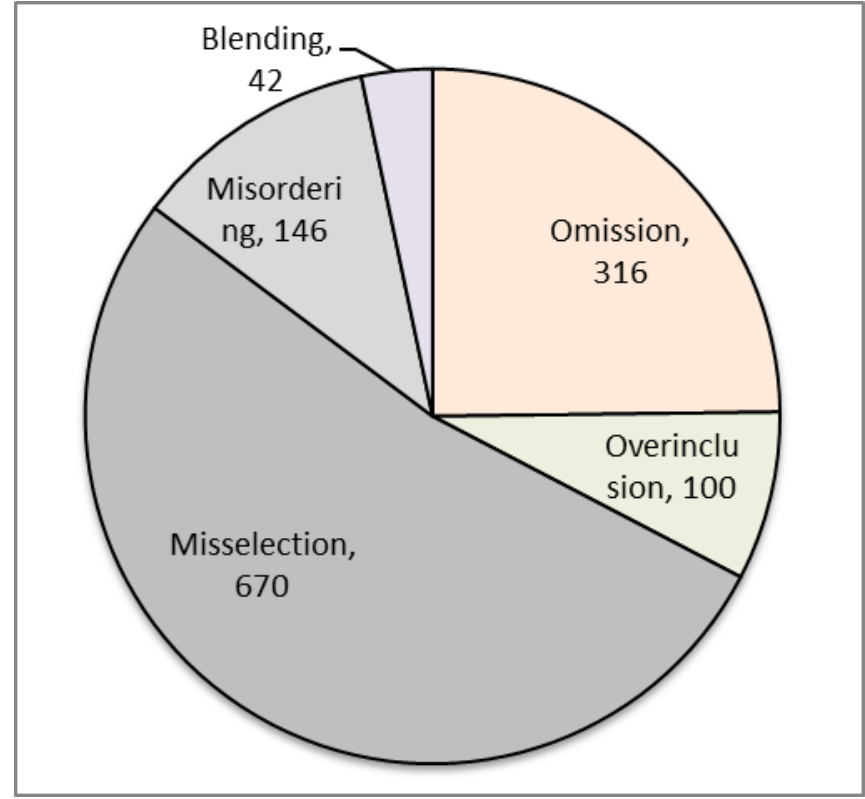

Figure 1. Recapitulation of Lexical Distortion

This shows that students do not know the correct form for the pemerintah. Respondents considered goverment to be the correct form while the correct one is government. It is 
Volume 5, Number 01, June 2019

potentially caused by the pronunciation difficulty of letter $r$ followed by $n$ faced by the student.

Successively, misordering, overinclusion, and blending are the next errors. The misordering error occurred as it follows the source language form resulting in unnatural translation. This error caused the meaning of the target language to be unclear eventually misunderstanding. For example: from for form which is a translation of word bentuk. The transition result showed a very different meaning to the source language. Thus, a deviation of meaning occurs. This type of error identical to the slip of tongue in spoken language (Miller, 2014, p. 198).

Misordering errors also occur at the phrase level. This was due to the influence of the mother tongue. This first language transfer is negative because the forms of the source language and the target language are far from equivalent. Some examples of misordering errors are as follows:

(1) .....free school give many impact positive first of all for of the success program. (TL) sekolah gratis memberi banyak dampak positif terutama untuk kesuksesan program wajib belajar 9 tabun. (SL)

(2) ....Education is a part important of buman in the life of the nation. (TL) Pendidikan merupakan bagian terpenting manusia dalam kebidupan berbangsa dan bernegara. (SL)

(3) ... order to creat buman sources quality and powerful in level international. (TL) dalam rangka menciptakan sumber daya manusia yang berkualitas dan berdaya saing tinggi di tingkat internasional. (SL)

The correct forms are:

\section{Misordering}

Impact positive

Part important

level international

\section{Correction}

Positive impact

Important part

International level

The next category is overinclusion. It happens when the respondents' ignorance in understanding both languages. They, therefore, produced distortion in their translation. Some of overinclusion errors were:

(1) school operational intendeed for the implementation of free education have positive impact (TL)

(2) Enought to belp school operational aid budget is spent an activities that support school achievement. (TL)

(3) The buman with quality will be decied the determinee go forward decine of nation (TL)

The three bold words are found in English vocabularies as follow:

\section{Overinclusion}

intendeed for

Enough

\section{Correction} intended for

Enough 
These errors occur as the respondent were careless in choosing the words. In addition, these errors have no correlation either to the first language or the target one.

The last type of error was blending. A list of blending forms can be found in Crystal (David Crystal, 2014). It happens as there were two possibly correct options. For examples:

(1) So can to say that education is determinant factor of a nation. (TL) Sehingga bisa dikatakan bahwa pendidikan merupakan faktor penentu kemajuan sebuah bangsa. (SL)

(2) Though a lot give to appreciate positive because school operational help that is meant to even out free school ... (TL) Meskipun banyak yang memberi apresiasi positif karena Bantuan Operasional Sekolah yang dimaksudkan untuk penyelenggaraan sekolah gratis ... (SL)

Data (1) is determinant factor translated from faktor yang menentukan is a blending error. The meaning of SL can be rendered into the word determinant as the factor is inclusive in meaning for faktor yang menentukan. Therefore, the combination of word factor and determinant is redundant. Thus, is determinant should best convey the meaning of SL. Similarly, data (2) a lot give to appreciate positive as equivalence of banyak yang memberi apresiasi positif. This translation can mean give positive appreciation or many people appreciate positively. Thus, one of them should reproduce the meaning of SL clearly.

\section{Sources of Errors}

The analysis of lexical distortion errors found three sources of errors: interlingual the mother tongue-influenced error) or L1 transfer (Jabeen, Kazemian, \& Shahbaz, 2015; Murad, 2013), intralingual (target language-induced error), and communication strategy. Based on theoretical studies, interlingual errors in relation to the transfer of the first language system or rule into a second language. Transfer consists of positive transfer; the first language has a system or rules similar to the second language. And, negative transfer also known as interference; the first language has a system or rules differs from the second language.

The second source of error is the intralingual related to the language being learned. These errors include misanalysis, hyper-correction, system alteration. This can be seen in the example given below.

1. Misanalysis, for example, the word people in people can join in role and to advance his national and state. The wrong analysis is on pronoun his for people. The correct pronoun should be their. 
Volume 5, Number 01, June 2019

2. Hypercorretion was found in nine years compulsory education program which in translated from wajib belajar 9 tahun. The error made by the respondent as he fails to make plural form year*s for the correct one as the head word of the phrase is program not year.

3. Simplification is shown in School who has many achievements... The error found in the use of pronoun who to refer word school. The word who should be used to refer to human. School is a noun. Therefore, the words that or which should be correct to use.

The third source of errors was the communication strategy that is holistic. Examples of errors in communication strategies were the use of the terms hypernym-hyponym and near-synonym in the selection of word requirement which was translated from kebutuban. Respondents view the word requirement is the correct equivalent because in the dictionary Indonesia-English word kebutuban is requirement. In fact, the word requirement in English-Indonesian dictionary means syarat dan keperluan. The word kebutuban are equated with kebutuban. This occurred as the learners assumed that one word can be changed by another word which has a close relationship (James, 1998). As a result, they are used differently in context. Thus, near-synonym error occurs. The correct form is need or necessity.

\section{The Distortion Impact}

The results confirm that there are two impacts occur caused by the lexical error, namely: local impact and global impact. Locally-generated errors are found in all categories of lexical distortions: omission, overinclusion, misselection, misordering, and blending.

Of these two, the global impact is known to be more prevalent than the local one. The translation produced by the respondents was still low in quality. The translation produced distortions both in form and meaning. Consequently, the source language message has not been fully communicated to the target language. As suggestion, a thorough improvement needs to be carried out.

\section{E. CONCLUSION}

Based on the results and discussion above, the lexical distortion consists of: a) ommission, b) overinclusion, c) misselection, d) misordering, and e) blending. There are 3 error sources: 1) the mother language interference or interlanguage, 2) the influence of target language or intralingual, and 3) the communication strategy. In addition, the lexical distortion impacted the communication of source language into target language locally and globally. As a result, the improvement of students' translation quality requires the students to practice more and 
more. In addition, the teaching of translation should be focused primarily on the selection of lexicon.

\section{REFERENCES}

Brislin, R. W. (1976). Translation: Aplications and Research. New York: Gardner Press.

Brown, H. D. (2007). Principles of Language Learning and Teaching (IV). New York: Pearson Education.

Corder, S. P. (1982). Error Analysis and Interlanguage. London: Oxford University Press.

David Crystal. (2014). Words in Time and Place. United Kingdom: Oxford University Press.

Dulay, H., Burt, M., \& Krashen, S. D. (1982). Language Two. Oxford: Oxford University Press.

Ellis, R. (1994). The Study of Second Language Acquisition. Oxford: Oxford University Press.

Ellis, R., \& Barkhuizen, G. (2005). Analysing Learner Language. Oxford: Oxford University Press.

Jabeen, A., Kazemian, B., \& Shahbaz, M. (2015). The Role of Error Analysis in Teaching and Learning of Second and Foreign Language. Education and Linguistics Research, 1(2), 52-62. https://doi.org/10.5296/elr.v1i2.8189

James, C. (1998). Errors in Language Learning and Use: Exploring Error Analysis. Longman.

Llach, M. P. A. (2011). Lexical Errors and Accuracy in Foreign Language Writing. UK. Multilingual Matters.

Murad, H. M. S. (2013). Error Analysis of Written English Essays: The case of Students of the Preparatory Year Program in Saudi Arabia. English for Specific Purposes World, 14(40), 122138.

Miller, D. G. (2014). English Lexicogenesis. United Kingdom: Oxford University Press.

Nida, E. A., \& Taber, C. R. (1982). The Theory and Practice of Translation. Leiden: E.J. Brill.

Richards, J. C., \& Schmidt, R. (2002). Longman Dictionary of Language Teaching and Applied Linguis-tics 3rd Ed. UK: Pearson Education Limited. Retrieved from www.pearsonbooks.com

Richards, J. C., \& Schmidt, R. (2010). Longman Dictionary of Language Teaching \& Applied Linguistics (IV). Great Britain: Pearson Education.

Setyawati, N. (2010). Analisis kesalahan berbahasa Indonesia: teori dan praktik. Surakarta: Yuma Pustaka.

Simatupang, M. D. S. (2000). Pengantar Teori Terjemahan. Jakarta: Direktorat Jenderal Pendidikan Tinggi. 